\title{
SIKAP GAYA KEPEMIMPINAN, KEPRIBADIAN: DAMPAKNYA TERHADAP KINERJA ORGANISASI
}

\author{
Mohammad Afandi \\ Pascasarjana \\ Universitas Muhammadiyah Gresik \\ fandyboyan@gmail.com
}

\begin{abstract}
The current leadership style is needed for every organization that wants to achieve the goals of their vision and mission and can improve the performance of the organization. This study aims to analyze the attitude of leadership style and personality on organizational performance. This study uses a quantitative method by taking a sample of 35 respondents by using a questionnaire spread. Respondents' research results show that leadership style has a significant influence on organizational performance and personality also has a significant influence on organizational performance. Attitudes, leadership style and personality have a simultaneous significant influence on organizational performance. Thus, these two variables have the same significant effect on organizational performance.
\end{abstract}

Keywords: gaya kepemimpinan, kepribadian, kinerja.

$\triangle$ Corresponding author:

Email Address : fandyboyan@gmail.com(Gresik, Jawa Timur)

Received 28 Januari 2021, Accepted 8 Pebruari 2021, Published 22 Pebruari 2021

\section{PENDAHULUAN}

Pendidikan menurut Rohiat (2008) memiliki peran dalam pembangunan nasional yaitu berperan dalam pengembangan sumber daya manusia (PSDM). Pendidikan merupakan salah satu upaya untuk membangun dan meningkakan mutu SDM menuju era globalisasi yang penuh dengan tantangan sehingga disadari bahwa pendidikan merupakan sesuatu yang sangat fundamental bagi setiap individu. Oleh karena itu, kegiatan pendidikan tidak dapat diabaikan begitu saja, terutama dalam memasuki era persaingan yang semakin ketat, tajam, berat pada abad millennium ini (Rivai dan Murni, 2012). Pendidikan dapat memberikan bekal untuk mengahadapi persaingan yang ketat di era globalisasi.

Suatu kepemimpinan dapat dikatakan efektif apabila gaya yang diterapkan dalam kepemimpinannya tersebut tidak hanya berorientasi pada tugas, tetapi juga cara yang digunakan dalam mempengaruhi bawahan. Dalam mempengaruhi bawahan, pemimpin harus berupaya agar dapat memberikan perasaan yang nyaman bagi para bawahan dalam menjalankan tugasnya, sehingga para bawahan dapat menjalankan tugas yang diberikan oleh kepala sekolah dengan senang hati tanpa ada rasa terpaksa.

Dalam proses kepemimpinan dikenal gaya kepemimpinan yang biasa digunakan pemimpin dalam melaksanakan tanggung jawabnya memimpin suatu organisasi. Gaya kepemimpinan secara umum adalah sebuah kualitas yang tersembunyi yang akan mendapatkan sebuah kepercayaan, kerjasama serta kejujuran akan menentukan kualitas atau lemahnya dalam mengembangkan organisasi yang dipimpinnya. Kualitas dalam hal ini adalah pembawaan, penampilan diri, perbuatan diri pada setiap waktu, komunikasi atau bahasa juga suatu sikap yang harus diperhatikan, suka menegur secara lisan jika diperlukan, kritik tercela atau pengumpatan setiap anggota kelompok atau unit harus dihindari, sikap suka menyindir atau sindiran tidak menghasilkan sesuatu yang baik, sedapat mungkin harus dapat menguasai diri sehingga jika digambarkan akan muncul sebuah ikhtiar. (Muwahid, 2013).

Gaya kepemimpinan kepala sekolah sangat berpengaruh pada pencapaian tujuan sekolah yang direncanakan sebelumnya, termasuk di dalamnya adalah bagaimana 
mengoptimalkan kinerja pendidik dan pengelola sekolah. Salah satu kompetensi yang harus dimiliki seorang guru adalah kompetensi professional. Untuk menjadi profesional, seorang guru diharuskan memiliki lima hal. Pertama, guru mempunyai komitmen pada siswa dalam proses belajarnya. Kedua, guru menguasai secara mendalam bahan atau mata pelajaran yang diajarkanya serta cara mengajarkanya pada siswa. Ketiga, guru bertanggung-jawab memantau hasil belajar siswa melalui berbagai teknik evaluasi. Keempat, guru mampu berfikir sistematis tentang apa yang dilakukanya dan belajar dari pengalamannya. Kelima, guru seyogianya merupakan bagian dari masyarakat belajar dalam profesinya. (Nurfuadi, 2012).

Kehadiran orang professional tentu diharapkan akan semakin mendekatkan mutu pendidikan Indonesia pada level yang dicitacitakan. Persoalan mutu mencakup proses dan hasil pendidikan serta terkait dengan kompetensi lulusan baik output maupun outcome. Sulhan (2013) kepemimpinan sangat berpengaruh terhadap kinerja para pegawai termasuk di dalamnya tenaga kependidikan di lingkungan kerjanya. Kepala madrasah sebagai pemimpin di lingkungan suatu lembaga pendidikan berpengaruh terhadap keberhasilan dan kegagalan sekolah karena merupakan pengendali dan penentu arah yang hendak ditempuh oleh sekolah menuju tujuannya. Dengan demikian gaya kepemimpinan sekolah berpengaruh terhadap kinerja tenaga kependidikan di sekolah untuk Pembinaan kinerja tenaga pendidikan di sekolah demi mencapai tujuan dan mewujudkan visi menjadi aksi.

Di antara faktor-faktor lain yang menunjang keberhasilan kinerja seorang guru adalah faktor kedisiplinan. Kedisiplinan harus ditanamkan kepada setiap individu, baik itu para guru ataupun siswanya. Sebagai pendidik, segala sikap dan perilaku yang dilakukannya, tentu akan dilihat dan dicontoh oleh siswanya. Sebagai tenaga pendidik, seorang guru dituntut untuk dapat mematuhi segala tata tertib yang telah diberlakukan di sekolah tersebut. Melemahnya kinerja guru bisa dilihat antara lain adanya gejala - gejala guru yang sering membolos/mangkir mengajar, guru yang masuk ke kelas yang tidak tepat waktu atau terlambat masuk ke sekolah, guru yang mengajar tidak mempunyai persiapan mengajar atau persiapan mengajarnya yang kurang lengkap. Kinerja guru yang kurang maksimal diantaranya disebabkan masalah waktu.

Gaya kepemimpinan yang diterapkan seorang pimpinan akan memengaruhi terhadap perilaku para guru sebagai bawahannya dan terciptanya suasana iklim kerja, apakah itu mengarah kepada hal yang positif ataupun sebaliknya. Sikap kepala sekolah yang kaku, monoton, tidak mempunyai kewibawaan, tidak tegas dan berperilaku acuh terhadap bawahan akan menciptakan suasana iklim pendidikan yang tidak nyaman, dan proses pembelajaran akan berjalan seadanya. Sedangkan sikap kepala sekolah yang luwes, berwibawa, tegas, adil dan perhatian terhadap bawahan atau guru dan siswa, akan menciptakan suasana pendidikan yang harmonis dan nyaman dalam pembelajaran bahkan akan terciptanya suatu prestasi pendidikan.

Berdasarkan latar belakang yang telah dipaparkan di atas, maka masalah yang akan dikaji melalui penelitian ini dapat dirumuskan dalam pertanyaan sebagai berikut :

1.Apakah Gaya Kepemimpinan berpengaruh terhadap Kinerja?

2.Apakah Kepribadian berpengaruh terhadap Kinerja?

Berdasarkan latar belakang dan rumusan masalah di atas, maka tujuan yang hendak dicapai dalam penelitian ini adalah untuk mengetahui:

1.Untuk menganalisis pengaruh Gaya Kepemimpinan terhadap Kinerja

2.Untuk menganalisis variable Kepribadian terhadap Kinerja

Kepemimpinan adalah suatu kegiatan dalam membimbing suatu kelompok sedemikian rupa sehingga tercapai tujuan kelompok itu yaitu tujuan bersama. Menurut (Hendyat dan Wasty, 1988) Pengertian umum kepemimpinan adalah kemampuan dan kesiapan yang dimiliki seseorang untuk dapat mempengaruhi, mendorong, mengajak, menuntut, dan menggerakan dan kalau perlu memaksa orang lain agar ia menerima pengaruh itu selanjutnya berbuat sesuatu yang dapat membantu pencapaian suatu maksud atau tujuan tertentu. Menurut Hamdan (2014) istilah kepemimpinan pada dasarnya berhubungan dengan ketrampilan, kecakapan, dan tingkat pengaruh yang dimiliki seseorang

Menurut Kurniadin dan Machali (2014) mengungkapkan bahwa gaya kepemimpinan 
adalah pola menyeluruh dari tindakan seorang pemimpin, baik yang tampak maupun yang tidak tampak oleh bawahannya. Seorang pemimpin dalam rangka memimpin sesuatu yang dipimpinnya tentunya memiliki cara atau teknik tersendiri dalam menjalankan suatu bentuk usaha kepemimpinan. Gaya kepemimpinan menurut Ngalim Purwanto (2014) adalah cara atau teknik seseorang dalam menjalankan suatu kepemimpinan yang mana cara tersebut merupakan pencerminan dari sifatsifat dasar seorang pemimpin.

Pendefinisian tersebut dapat dipahami bahwa gaya kepemimpinan merupakan teknik, cara, dan tipe atau pola tingkah laku yang ditunjukkan seorang pemimpin ketika berusaha memengaruhi tingkah laku orang lain seperti yang akan dipersepsikan oleh orang-orang yang akan dipengaruhi oleh pemimpin tersebut.Gaya kepemimpinan ini diperlukan untuk mengelola tiga unsur dalam kepemimpinan yang saling berkaitan yaitu unsur manusia, unsur sarana, dan unsur tujuan. Untuk dapat memperlakukan ketiga unsur tersebut secara seimbang dan proporsional, seorang pemimpin harus memiliki pengetahuan, kecakapan, dan keterampilan yang diperlukan dalam kepemimpinannya.

Secara sederhana dapat dikemukakan bahwa kinerja adalah unjuk kerja seseorang yang ditunjukan dalam penampilan (Mulyasa, 2013). Sudarmayanti menjelaskan (Shulhan, 2013) kinerja dapat diartikan prestasi kerja, pelaksanaan kerja, pencapaian kerja atau hasil kerja atau unjuk kerja atau penampilan kerja. Sedangkan menurut Mangkunegara dalam Barnawi dan Arifin (2014) kinerja adalah hasil kerja secara kualitas dan kuantitas yang dicapai oleh seorang pegawai dalam melaksanakan tugasnya sesuai dengan tanggung jawab yang diberikan kepadanya.

Beberapa penjelasan di atas dapat disimpulkan bahwa kinerja adalah kemampuan dan prestasi yang dimiliki oleh seseorang dalam melaksanakan tugas dan tanggung jawabnya. Sedangkan kinerja guru adalah kemampuan yang ditunjukan oleh guru dalam melaksanakan tugas atau pekerjaannya (Rachmawati dan Daryanto, 2013). Jadi, kinerja guru adalah kemampuan yang dimiliki oleh guru dalam melaksanakan tugas dan tanggungjawabnya sebagai pendidik dan melaksanakan tugas tambahan di luar pembelajaran.

Hipotesis
H1: Diduga ada pengaruh Gaya kepemimpinan terhadap Kinerja

H2: Diduga ada pengaruh Kepribadian terhadap Kinerja

\section{METODE PENELITIAN}

Jenis penelitian yang digunakan dalam penelitian ini adalah penelitian kuantitatif dengan pendekatan inferensial. Metode penelitian kuantitatif merupakan salah satu jenis penelitian yang spesifikasinya adalah sistematis, terencana dan terstruktur dengan jelas sejak awal hingga pembuatan desain penelitiannya. Menurut Sugiyono (2013), metode penelitian kuantitatif dapat diartikan sebagai metode penelitian yang berlandaskan pada filsafat positivisme, digunakan untuk meneliti pada populasi atau sampel tertentu, teknik pengambilan sampel pada umumnya dilakukan secara random, pengumpulan data menggunakan instrumen penelitian, analisis data bersifat kuantitatif/statistik dengan tujuan untuk menguji hipotesis yang telah ditetapkan.

1. Subyek Penelitian

Subyek penelitian adalah pelaku utama dalam penelitian ini, yang dapat memberikan data mengenai variabel yang diteliti. Subjek dalam penelitian ini ialah kepala sekolah MTs Hasan Jufri Bawean.

2. Responden Penelitian

Menurut Sugiyono (2013) mengartikan populasi sebagai wilayah generalisasi yang terdiri atas: obyek/subyek yang mempunyai kualitas dan karakteristik tertentu yang ditetapkan oleh peneliti untuk dipelajari dan kemudian ditarik kesimpulannya.Sesuai dengan pendapat tersebut maka yang dijadikan populasi oleh peneliti adalah guru yang bekerja di Sekolah MTs Hasan Jufri Bawean.

Sampling jenuh adalah teknik penentuan sampel apabila semua anggota populasi digunakan sebagai sampel (Sugiyono, 2012). Penentuan sampling ini sering dilakukan bila jumlah populasi relatif kecil, kurang dari 35 orang, atau penelitian yang ingin membuat generalisasi dengan kesalahan yang sangat kecil. Istilah lain sampel jenuh adalah sensus, dimana semua anggota populasi dijadikan sampel. Teknik pengambilan data dalam penelitian ini dengan menggunakan metode sebagai berikut :

Kuesioner merupakan teknik pengumpulan data yang dilakukan dengan cara 
memberi seperangkat pertanyaan atau pernyataan tertulis kepada responden untuk dijawabnya Sugiyono (2013). Koesioner dalam penelitian ini dibuat dalam bentuk skala likert yang berkaitan dengan variabel variabel yang diteliti berdasarkan indikator variable (X1) Gaya kepemimpinan dan (X2) Kepribadian terhadap (Y) Kinerja. Teknik analisis data menggunakan Analisis regresi linier berganda dimaksud untuk menganalisis pengaruh dari variabel (X1) Gaya kepemimpinan, (X2) Kepribadian, terhadap (Y) Kinerja.

\section{HASIL}

Hasil pengujian terhadap hipotesis yang diajukan dalam penelitian ini secara ringkas ditunjukkan Tabel 1. sebagai berikut :

Tabel 1. Hasil Uji Hipotesis

\begin{tabular}{|l|l|l|l|l|}
\hline $\begin{array}{l}\text { Hubungan antar } \\
\text { Variabel }\end{array}$ & B & $\mathrm{t}$ & Sig & Keterangan \\
\hline $\begin{array}{l}\text { Gaya } \\
\text { Kepemimpinan -> } \\
\text { Kinerja }\end{array}$ & 0.334 & 1.416 & 0.007 & Signifikan \\
\hline $\begin{array}{l}\text { Kepribadian -> } \\
\text { Kinerja }\end{array}$ & 0.305 & 1.404 & 0.000 & Signifikan \\
\hline
\end{tabular}

Sumber : Out SPSS, data diolah (2020)

Pengujian hipotesis dan koefisien pengaruh langsung antara variabel variabel penelitian, dapat dilihat dari nilai koefisien jalur dan titik kritis (CR) yang siginifikan pada $\alpha=0.05$. Hasil pengujian model sebagaimana nampak pada gambar diatas menunjukkan bahwa semua koefisien jalur memiliki pengaruh yang signifikan. Hasil uji menjelaskan tentang pemahaman bahwa kedua variabelberpengaruh terhadap kinerja guru, sebagaimana diujikan pada tahap berikutnya.Berikut secara lengkap akan diuraikan satu persatu pengujian hipotesis sebagaimana disebutkan pada bab sebelumnya.

\section{Uji F}

Berdasarkan output penelitian diketahui nilai signifikansi untuk pengaruh $\mathrm{X} 1$ dan $\mathrm{X} 2$ secara simultan terhadap kinerja adalah sebesar 0,000 $<0,05$, dan nilai $F$ hitung $13.323>\mathrm{f}$ tabel, sehingga dapat disimpulkan bahwa $\mathrm{H} 3$ diterima yang berarti terdapat pengaruh $\mathrm{X} 1$ dan $\mathrm{X} 2$ secara simultan. Hasil uji terhadap hipotesis secara simultan yang diajukan dalam penelitian ini secara ringkas ditunjukkan Tabel 2.
Tabel 2. Hasil Uji F

ANOVA $^{b}$

\begin{tabular}{|rl|r|r|r|r|r|}
\hline Model & & $\begin{array}{l}\text { Sum of } \\
\text { Squares }\end{array}$ & $d f$ & $\begin{array}{c}\text { Mean } \\
\text { Square }\end{array}$ & \multicolumn{1}{|c|}{$F$} & Sig. \\
\hline 1 & $\begin{array}{l}\text { Regre } \\
\text { ssion } \\
\text { Resid } \\
\text { ual } \\
\text { Total }\end{array}$ & 3.713 & 2 & 1.856 & $\begin{array}{r}13.32 \\
3\end{array}$ & $.000^{\mathrm{a}}$ \\
& 8.171 & 34 & 32 & .139 & & \\
& & & & \\
\hline
\end{tabular}

a. Prediktor: (Constant), total_x2, total_x1

b. Variabel Dependent: total_y

Sumber : data diolah (2020)

\section{PEMBAHASAN}

H1: Pengaruh Gaya Kepemimpinan Terhadap Kinerja

Pengujian Hipotesis H1 Dari tabel 4.10 di atas dapat dilihat nilai Beta adalah sebesar 0,334 dengan signifikansi dibawah 5\% yang ditunjukkan dengan nilai t- statistik 1.416 lebih besar dari nilai t-tabel sebesar 1.306. Nilai original sample estimate positif mengindikasikan bahwa Gaya Kepemimpinan berpengaruh positif dan signifikan terhadap Kinerja Guru. Berdasarkan hasil regresi tersebut dapat disimpulkan bahwa hipotesis pertama diterima.

H2: Pengaruh Kepribadian Terhadap Kinerja Pengujujian Hipotesis $\mathrm{H} 2$ dari Tabel 1. dapat dilihat nilai Beta adalah sebesar 0,305 dengan signifikansi di bawah 5\% yang ditunjukkan dengan nilai t- statistik 1.404 lebih besar dari nilai t-tabel sebesar 1.306. Nilai original sampel estimate positif mengindikasikan bahwa kepemimpinan berpengaruh positif dan signifikan terhadap Kinerja guru. Berdasarkan hasil regresi tersebut dapat disimpulkan bahwa hipotesis kedua diterima.

H3: Pengaruh Gaya kepemimpinan dan Kepribadian secara simultan Terhadap Kinerja

Uji Hipotesis H2 dari tabel 4.10 di atas dapat dilihat nilai signifikansi adalah sebesar 0,000 dengan signifikansi di bawah $5 \%$ yang ditunjukkan dengan nilai $\mathrm{F}$ hitung 13.323 lebih besar dari nilai F-hitung bahwa gaya kepemimpinan dan kepribadian berpengaruh positif dan signifikan secara simultan terhadap 
Kinerja. Berdasarkan hasil regresi tersebut dapat disimpulkan bahwa hipotesis ketiga diterima.

\section{KESIMPULAN}

Berdasarkan perhitungan dengan menggunakan SPSS, maka pengujian hubungan antar variabel-variabel diperoleh hasil sebagai berikut 1. Variabel Gaya kepemimpinan (X1) berpengaruh positif dan signifikan terhadap Kinerja. Hasil ini bermakna bahwa semakin tinggi tingkat nilai Gaya Kepemimpinan maka semakin meningkat pula kinerja guru tersebut. Tingkat penilaian Gaya kepemimpinan yang rendah akan secara otomatis tingkat penilaian kinerja guru juga rendah karena setiap perilaku yang dilakukan selama disekolah akan mencerminkan kinerja yang baik atau buruk.

2. Variable Kepribadian (X2) berpengaruh positif dan signifikan terhadap Kinerja. Hasil ini bermakna bahwa semakin tinggi tingkat nilai kepribadian maka semakin meningkat pula kinerja tersebut. Tingkat penilaian kepribadian yang rendah akan secara otomatis tingkat penilaian kinerja guru juga rendah karena setiap perilaku yang dilakukan selama disekolah akan mencerminkan kinerja yang baik atau buruk.

3. Variable Gaya kepemimpinan (X1), Variable Kepribadian (X2) berpengaruh positif dan signifikan secara simultan terhadap Kinerja. Hasil ini bermakna bahwa semakin tinggi tingkat nilai Gaya Kepemimpinan dan kepribadian maka semakin meningkat pula kinerja tersebut. Tingkat penilaian Gaya kepemimpinan dan kepribadian yang rendah akan secara otomatis tingkat penilaian kinerja guru juga rendah karena setiap perilaku yang dilakukan selama disekolah akan mencerminkan kinerja yang baik atau buruk

\section{DAFTAR PUSTAKA}

Anwar, Moch. Idochi. 2004. Administrasi Pendidikan dan Manajemen Biaya Pendidikan .Bandung : Alfabeta.

Barlian, Ikbal. 2013. Manajemen Berbasis Sekolah Menuju Sekolah Berprestasi. Jakarta: Erlangga.

Dadang. 2010. Supervisi Profesional. Bandung: Alfabeta.

Danim, Sudarwan. 2010. Profesionalisasi dan Etika Profesi Guru. Bandung: Alfabeta.
Djamarah, Syaiful Bahri. 2011. Psikologi Belajar. Jakarta : Rineka Cipta.

Dimyati, Hamdan. 2014. Model Kepemimpinan dan System Pengambilan Keputusan. Pustaka Setia: Bandung.

Efendi, Nur. 2015. Islamic Educational Leadership; Memahami Integrasi Konsep Kepemimpinan di Lembaga Pendidikan Islam. Yogyakarta: Parama Publishing.

Ferdinand, Augusty T. 2006. Metodologi Penelitian Manajemen. Semarang : CV. Indoprint.

Iqbal, Abu Muhammad. 2015. Pemikiran Pendidikan Islam. Yogykarta: Pustaka Pelajar .

Mulyasa. 2013. Pengembangan dan Implentasi Pemikiran Kurikulum. Bandung : Rosdakarya.

Muwahid, Shulhan. 2013. Model Kepemimpinan Kepala Madrasah dalam Meningkatkan Kinerja Guru. Yogyakarta: Teras.

Nawawi, Hadari. 1993. Metode Penelitian Sosial. Yogyakarta : Gajah Mada University Press.

Nasution.1995. Dikdaktik Asas-asas Mengajar. Jakarta: Bumi Aksara.

Ngalim, Purwanto. 1995. Ilmu Pendidikan Teoritis dan Praktis. Bandung : Remaja Karya.

Penilaian Kinerja Profesi Guru dan Angka Kreditnya. Yogyakarta: Gava Media

Rohiat. 2008. Manajemen Sekolah - Teori Dasar dan Praktik Dilengkapi dengan Contoh Rencana Strategis dan Rencana Operasional. Bandung: PT. Refika Aditama.

Rusdiana, A dan Yeti Heryati. 2015. Pendidikan Profesi Keguruan. Bandung: Pustaka Setia.

Saifullah. F.2016. Hubungan antara Konsep Diri Dengan Bullying Pada Siswa- Siswi SMP (SMP Negeri 16 Samarinda) eJournal Psikologi, 2016, 4 (2): 200-214.

Sugiyono, 2013, Metodelogi Penelitian Kuantitatif, Kualitatif Dan R\&D. (Bandung: ALFABETA)

Supardi. 2013. Aplikasi Statistika dalam Penelitian Konsep Statistika yang Lebih Komprehensif. Jakarta: Change Publication.

Sulhan Muwahid dan Soim. 2013. Manajemen Pendidikan Islam: Strategi Dasar Menuju 
Peningkatan Mutu Pendidikan Islam. Yogyakarta: Teras.

Team Penerjemah Departemen Agama. 2005. Al-Qur'an Dan Terjemahnya. Bandung: CV J-ART.

Wasty, Soemanto dan Hendyat Soetopo .1984. Kepemimpinan dan Supervisi Pendidikan Jakarta : Bina Aksara. 